\title{
EM RELAÇÃ0 Á PAREDE DOS OPERARIOS
}

(Carta ao Dr. A. Covello, Redactor da Gazeta)

"Meu Collega:

Tendo o Collega sido o unico jornalista que, em bel lissimos artigos, prenunciou os lutuosos acontecimentos que acabam de se desenrolar em nossa capital, é ao collega que peço agazalho para essas poucas linhas, inspiradas pelo meu sentimento de humanidade. Ao ler seus artigos sobre a afflictiva situação da classe operaria, tinha eu sempre a impressão de que me palpitava entre as mãos o seu jornal. Suas palavras recordavam-me a voz das procellarias que, quando o oceano apparenta perfeita calma, annunciam as grandes tempestades.

Ainda que haja, entre os dirigentes do nosso Estado, pessoas a quem voto o maior respeito, cumpre que, acudindo á voz do dever, diga eu duas palavras sobre o €rro que commetteram, não attendendo ás animadversões do Collega.

Refere-se que o rei consorte da rainha Victoria tinha como principio que o chefe de Estado deveria ser a pessoa melhor informada da situação politica do paiz que dirige. A Sciencia da Administração, a que ultimamente tenho dedicado minha actividade intellectual, aciencia ainda em formação, tem como regra de governo 
que o administrador deve estar seguro sempre, pela estatistica e pelos inqueritos, de tudo quanto occorre na sociedade, para, com felicidade, se ingerir no andamento dos negocios publicos. $\mathrm{O}$ governo de $\mathrm{S}$. Paulo, que conta em seu seio mestres a quem muito respeito, não precisava ler estatisticas, nem proceder a inqueritos, por que o Collega o esclareceu sobre a gravidade da situação, quando a fome ameaçou acossar os operarios, e lançal-os transformados em féras, ás praças publicas. Vou apontar os erros do nosso governo, unico, — duro é dizel-o, - infelizmente, responsavel, em razão de sua imprevidencia, pelo sangue de operarios famelicos, derramado nas ruas desta capital. Governo honrado, é certo, bem intencionado, mas de uma imprevidencia verdadeiramente infantil, pois não posso admittir nos administradores deste Estado a ignorancia dos principios da importante sciencia que se denomina Sciencia da Administração, com a qual se póde tornar uma realidade o que foi conquistado pela Economia Social, o que é pregado por Gide e Nitti, o defensor dos principios catholicos sobre o modo de tratar os trabalhadores. Direi os erros, e indicarei os remedios. que deveriam ter sido empregados.

Quando as grandes casas industriaes, dispondo de elevados capitaes, começaram a açambarcar os generos de primeira necessidade, deveria o nosso governo ter logo tomado medidas para adquirir o sufficiente, afim de prover, a preços ordinarios, as classes laboriosas, no momento de penuria. A "Gazeta" denunciou o facto, e o governo de São Paulo foi menos previdente que o do honrado marechal Floriano Peixoto, em 1893, não obstante ser o marechal ho'mem de pouca cultura em sciencias sociaes, como dizia elle mesmo.

Além deste primeiro erro, commetteu o governo um segundo, quando deixou sem emprego os operarios que eram despedidos das fabricas. E' o caso em que o Esta. do se torna industrial: abre fazendas, faz obras publicas, 
suppre a actividade particular. Devemos lembrar-nos de que, durante a secca do Ceará, trataram os nossos governos de dar trabalho aos habitantes da região flagellada. Já ninguem hoje contesta que, com a escola de Manchester do "laisser faire, laisser passer", não é possivel administração, tal qual é concebida modernamente. O Estado "gendarme" não é mais de nosso tempo: é um fossil. Hoje o direito ao trabalho, entendido com certa cautela, é uma acquisição da sciencia. Em nosso Estado, quantos serviços uteis poderia fazer o governo, si se houvesse aproveitado dos braços desoccupados! Para se cohonestar a inercia governamental, tem-se dito que o operario de cidade não póde ser empregado na lavoura, e que a lavoura é a unica industria que poderia acudir aos desoccupados nesse momento. Entretanto, no Rio de Janeiro, fala-se em occupar os marinheiros dos navios que tomámos dos allemães em trabalhos agricolas... Comparemos o que se passa no Brasil com o que se passa na Inglaterra e na França, onde a palavra inspirada de Gide explica que, com a intensificação do trabalho, durante a guerra, augmentou-se o bem estar economico do povo, sendo isto devido ás acertadas medidas de organização administrativa do trabalho pelo Estado. Acha-se no governo o illustre mestre Candido Motta, que sabe que, em materia penal, se julga que a severidade das penas nada adeanta para a diminuição da criminalidade; e que só devemos esperar algum resultado dos substitutivos penaes, graças a uma segura e intelligente administração. Isto mesmo aprendi com um mestre muito chegado ao governo, o illustre politico dr. Raphael Sampaio, de quem recebi licções utilissimas de Criminologia e de Direito Penal. Temos, em assumptos de administração, um deputado conhecedor do que ha de mais adeantado, illustre economista e sabio na difficil Sciencia da Administração. Refiro-me ao dr. Dario Ribeiro. Pois bem! Não deveria o governo ter tido a prudencia de se deixar guiar 
por esses mestres, como fazem os governos dos povos cultos? Será possivel que o governo os não tivesse ouvido? Si os ouviu, receberia delles o conselho de muitas medidas já sobejamente conhecidas de quantos possuem os segredos da administração dos negocios publicos.

O terceiro erro do governo foi deixar a capital no momento angustioso. Quando o povo começava a sentir as torturas da fome, o pessoal dourado da alta sociedade sahia da capital em busca de clima mais ameno e de repouso, e era acompanhado pelos nossos administradores e por muitos dos nossos politicos. Conta-se que, ao celebrar-se uma das ultimas festas da côrte de França, em 1789, Marat espiava, cheio de bilis e com os olhos piscos, todo o luxo da brilhante companhia, e traçava o plano da revolução que deveria empapar em sangue o solo da França.

Sabe o nosso governo quantos Marats, com os olhos empannados de lagrimas e o coração despedaçado, viam passar, pelos bairros industriaes dos suburbios desta capital, os alegres romeiros das villegiaturas doces, gente para quem é a vida um sorriso eterno? Esqueceu-se o nosso governo do que ensinam os economistas sobre o luxo de rua? Não é de crer: os doutos homens a quem está confiada a direcção do Estado sabem perfeitamente tudo quanto as summidades da Economia Politica têm escripto sobre o altissimo problema do luxo.

Chego ao fim, meu collega, ao termo dessa via dolorosa!... Rompem-se os diques, a classe operaria invade a cidade, faminta, allucinada, pedindo, não "panem et circenses", mas "panem et opus"... E' o exercito da miseria, é a fome, é o desespero, é a revolta contra todas as injustiças sociaes, que ruge, chora, clama, pragueja, é comtudo aquella gente por quem Christo morreu na cruz, e por quem o mais lucido espirito do Seculo XIX, Leão XIII, escreveu a bella encyclica "De rerum nova- 
rum". Como recebeu o governo essa multidão, que vinha, sob a egide do Evangelho e dos paragraphos 8. e 9. do artigo 72 de nossa Constituição Federal? Demais já $0^{\circ}$ disseram os jornaes, para vergonha do povo brasileiro. Ninguem ignora que, nesses momentos angustiosos de loucura publica; com tanta agudeza estudadas por Bagehot, se junta aos infelizes um grupo de malfeitores, contra o qual toda a severidade é louvavel. Mas... severidade com a possivel moderação. Ora, meu collega, poderá o governo, composto de homens que são conscienciosos, affirmar, deante de Deus e dos homens, que foram injustas as queixas da imprensa contra as inuteis violencias? Eu posso assegurar que não tenho noticia de povo mais submisso ás ordens superiores do que o que vi agora a pedir soccorro pelas ruas desta capital, todos obedeciam á ordem de "circular", ninguem se revoltava contra a acção da policia. Está claro, clarissimo que só me refiro aos grevistas e ao povo do trabalho, e não ao grupo de arruaceiros, contra os quaes louvabilissima era a severidade policial: o mal da policia estava justamente em não procurar, "no limite do possivel", separar desgraçados trabalhadores dos infames desordeiros. Disto, porém, já tratou a imprensa, a deusa protectora de nossos direitos.

O que porém, mais profundamente me impressionou foi a condemnavel indifferença dos representantes do povo: fóra os senadores e jornalistas drs. Julio de Mesquita e Carlos de Campos, nenhum deputado, nenhum senador se incommodou com a sorte do povo, nenhum procurou tornar uma realidade a Constituição Federal. Foram os jornalistas, que não recebem do povo nem subsidio, nem mandato, que se moveram, e que procuram obter uma conciliação.

Si o collega me honrar publicando estas linhas, antes de terminada a parede dos operarios, servirão ellas para concitar os representantes legaes do povo a obterem uma solução ao premente problema que se apresenta neste 
momento terrivel, perturbando o trabalho e dando ao mundo uma tristissima idéa de nossa administração, particularmente comparada com a dos povos europeus, que, em conjunctura muito mais difficil, estão procedendo com acerto admiravel.

Possam essas linhas, que traduzem as idéas que tenho de defender, dentro de poucas semanas, ante a douta Congregação da Faculdade de Direito desta capital, receber da imprensa, ultimo baluarte de nossa liberdade, o mesmo applauso que tributei á acção dos nossos jornalistas, e concorrer para a harmonia entre patrões e operarios.

Julho de 1917.

Braz de Sousa Arruda,

Docente da Faculdade. 